Vol. 3, No. 3, September 2021, pp. 386-391,doi.org:10.52567/pjsr.v3i3.262

www.pjsr.com.pk

\title{
WATER DISPUTES IN SOUTH ASIA: A COMPARATIVE STUDY OF BANGLADESH AND PAKISTAN
}

\author{
Azhar Mahmood Abbasi \\ Lecturer, Pakistan Studies, NUML University H-9, Islamabad \\ azharabbasi@numl.edu.pk \\ Ayaz \\ Lecturer in Pakistan Studies, NUML University H-9, Islamabad \\ ayazakhtar@numl.edu.pk \\ Munawar Ali Mahar \\ Lecturer in International Relation, NUML University H-9, Islamabad \\ munawarali@numl.edu.pk
}

\begin{abstract}
The problem of improper water management and water resources is very common in developing countries and especially in South Asia. Three out of seven countries including Bangladesh, Nipal and Pakistan are involved in Water sharing conflicts with each other. This research paper highlights the water disputes and various water sharing treaties in South Asia especially in India, Bangladesh and Pakistan, with a comparative evaluation of past and future trends, followed by suggestions for a sustainable future cooperation. The paper will also have focused on the historical water conflicts of Indian state with the other South Asian countries especially with Pakistan and Bangladesh. The first part of the paper deals with water issues erupted between India and Pakistan such as Bagliar Dame water issue, Kishanganga water conflict, and Wullar Barrage etc and treaty signed to resolve the water disputes between these two states such as Indus Water Treaty. The second part of the paper highlight the water disputes between India and Bangladesh and also focuses on the Accord signed between the two states including the Teesta water Treaty, and Farraka agreement etc. At the end, the paper will provide the comparison of both Pakistan and Bangladesh's water disputes with India.

Key Words: Water disputes/Issues/Conflict, Bangladesh, Pakistan, Water Resources, Kishanganga, Wullar Barrage, Teesta, Farraka Accord/Treety, Indus water treaty.

\section{INTRODUCTION}

Water is the basic need of life, which is used for cooking, bathing and in industries. In ancient cultures, agriculture was the basic occupation which is why water represent the very essence of life. The Roman people, for the first time, provided water through proper channel to their urban areas to fulfill their need of water. There is $71 \%$ water on the surface of earth, but very little is for the human use. In the countries' political history, it played a pivotal role. It also played role in religion, tradition, and art as the cleanliness of soul through water is also a belief in many religions.

There are many factors responsible for scarcity of water resources world-wide, including the urbanization, steady increase in population, industrialization and environmental degradation. Those challenges led towards water shortages, and in turn, resulting in increasing international conflicts over water. Such disputes are getting more novel and complex, involving not only legal entities but both states and individuals.

Likewise, the disputes on Water are very common in South Asian region especially in Pakistan and Bangladesh. In both cases, India has a sole authority to stop and have a control over water and creating problems for the Bangladesh and Pakistan since 1950s (Salman, 2000).
\end{abstract}


Water Disputes in South Asia: A Comparative Study of Bangladesh and Pakistan

1970s decade proved a rapid change for three South Asian Giants; India, Pakistan and Bangladesh. The honeymoon which had started in 1971 between Dacca and New Delhi ended, when later bickered over shared boundaries and water drove both at the brink of Divorce (Wolpert, 1982).

\section{RESEARCH METHODOLOGY}

The methodology of this research work is qualitative and descriptive. For the data collection, secondary sources have been consulted, which was collected though different Journal Articles, books, newspapers etc.

\section{FINDINGS}

\section{History and Status of Water Disputes in South Asia}

There are seven countries in South Asia with population of more than 1.3 billion people, of which more than 1 billion are living in India. The unique geography of the sub-continent isolated this region from the rest of the world except some passes in Himalayas. Pakistan, Bangladesh and Nepal form more than a quarter billion population of the total of South Asia. In South Asia, the huge population of these seven countries made it populous and a huge pressure on the environment as well as created a problem of water crisis (Robie \& Roy, 1997).

The water disputes, which was started in South Asian countries and created permanent problems among them need to be resolved. Political and Geographical positions of these countries are creating base for dispute. Now the question is how to resolve this dispute in future. Although, in the past, Indus water treaty was signed for the purpose to resolve the water dispute of South Asian countries, but still they are lacking cooperation and violating the treaty (Condon, et all., 2009).

As India is the largest and powerful country of the region, instead of resolving their problems, it is creating disputes with its' neighbour countries especially issues of water resources distribution on rivers. These issues need to resolved to supply water to other neighbours. The need of water has increased with an increase in population. It is also used in industry and for agriculture (Condon, et all., 2009).

\section{India and Pakistan}

Both countries are competitors from the moment they got independence from British in 1947. The boundary commission at the time of partition disclosed the Radcliff Award provided access to Kashmir from India by allocating Muslim majority area Gurdaspur to India. Kashmir has been considered as integral part of Pakistan. According to geographical contiguity and in terms of population, Kashmir could be merged with Pakistan as most of the rivers water coming down from Kashmir to Pakistan (Kureshy, 1997).

However, both countries are not properly utilizing the water of the rivers divided between them according to Indus water treaty. Water resources that are lacking in some cases have been instrumental to promote cooperation and establish peace on the water dispute between both countries. The 1960 agreement between India and Pakistan is a clear example in the region and the Ganges water agreement is second example in South Asia. However, both agreements between the neighboring countries are needed to be resolved peacefully with cooperation otherwise, these will create future conflict among them (Noshab \& Mushtaq, 2001).

The water issue between India and Pakistan is complex dispute. In fact, both the countries have some ideological, historical and religious differences over the century. Generally, it is said that the Kashmir issue is bone of content between Pakistan and India from the independence time. As according to viceroy announcement, it would be the part of Pakistan but unfortunately, it was against the will and wish of Kashmiri people. In fact, the resources of fresh water, which is crucial to irrigate lands for the development of agriculture and industry, remain an ongoing issue between Pakistan and India. While an old treaty of Indus has administered their three eastern and three western rivers, both countries since independence are in a continued tussle over clarification of the agreement, besides their own explanation with construction of dam projects on either side is always a cause of disagreement between them (Kureshy, 1997). 


\section{A. History of Disputes between India and Pakistan}

Pakistan and India got independence since August 1947 as separate states from British. During the partition process, assets were divided between Pakistan and India. Nevertheless, mostly injustices were seen. Some issues were remained unresolved even today, while some were given little importance like water resources. In particular, River Indus and its tributaries i.e. the, River Ravi, Sutlej, Beas, Chenab and Jhelum which flow naturally from India into Pakistan. On April 1, 1948, India created problems for Pakistan to destroy their crops when they stopped water. This gave birth to water disputes.

For instance, in 1948, India suspended the natural flow of the River Sutlej into Pakistan, which badly harmed the standing crops in Pakistan. Resentments between both countries over water issue started from 1960 (Sen, 1988).

The issue of water resources remained a headache for Pakistan up to fifty years and even still, the Indus Water Treaty that is live example of its proof of this conflict resolution. Although, there is an emerging need of water, it is a kind of threat to the Indus water treaty as it does not fulfill the need of water during the time when there is a severe need in October to March as compare to those months in which it is double of the said months. Its great impact lies in the storage of the River Chenab water into Pakistan, and Jhelum and Neelum rivers to the Wullar Barrage and Kishanganga Project. The accord which was signed in 1991, permitted Pakistan 114 MAF water to all provinces of the country, but canal supplies averaged at $99 \mathrm{MAF}$, which was $13.4 \%$ less than the permitted water flow. The average in seventies flow of water and then after 1976, if we study the average flow of water, it was less than $2.91 \%$ of the pre-storage period. As Pakistan lies above the tropic of Capricorn, which means that the weather condition is extreme in the country. Rainfall condition is different, less from $100 \mathrm{~mm}$ in the dry part of Baluchistan and in Sindh, more than 1,500 millimeter in rainy mountains (Ahmed, 2012).

As this is a geographical fact that both Pakistan and India depend on the water of river Indus system. One another fact that the five rivers and the tributaries which are flowing in Pakistan, India can control that water and harm Pakistan (Condon, et all., 2009).

However, the Indus Water Treaty created a legal framework for governing water resources, but it failed to mitigate several important areas of tension. Specifically, three key points of the treaty have given to subsequent disputes. First, Pakistan is wholly dependent for its fresh water supply upon the Indus River basin system. While dwindling groundwater provides for some of Pakistan's needs, the Indus and its tributaries including its prominent agricultural sector represent the only source of surface waters for the entire country. Second, the headwaters of all six rivers are within Indian Territory, and, accordingly, the Indian government can significantly stop the flow of water into Pakistan.

Third, while India is not permitted to build projects on the Indus, Chenab and Jhelum rivers to store and divert water flowing to Pakistan, many of India's current or proposed dam projects done both. To compound matters, the Indus, Chenab, Jhelum, all flow through the volatile region of Jammu and Kashmir, where India and Pakistan are busy in sporadic fighting during a decades-long territorial dispute. Together, these elements provide a basis for several major disputes as Pakistan and India seek to meet growing domestic water demand (Condon, et all., 2009).

\section{B. Existing Clashes between Pakistan and India}

The difference between the issue of Pakistan and India is the natural flow of rivers water and political boundaries, tied with the Indus Water Treaty and this treaty gave birth to a number of issues between the rivals' countries. The most current and important disputes involve Wular Barrage/ Tulbul Navigation the Baglihar Dam, the Kishenganga Dam and Indian retention of water from the Beas, Sutlej and Ravi rivers (Condon, et all., 2009)

\section{The Baglihar Dam}

India has claimed that it has never interfered on the Indus water river flowing to Pakistan. The river flows through Jammu and Kashmir (disputed territory) from India directly, and then into Pakistan. The Baglihar project will produce 450 Mega Watt hydroelectricity; later will be upgraded with potential of $900 \mathrm{MW}$, 
Water Disputes in South Asia: A Comparative Study of Bangladesh and Pakistan

144.5-meter concrete gravity dam. The project also comprises considerable storage capacity and gated spillways that would allow for reduction of sedimentation flood-control for the region. Pakistan and India started proper dialogue in the year 2000 to resolve the issue. India started with the Baglihar project of hydroelectric plant. In this regard, on January 15, 2005, Pakistan wanted to address the conflict in the World Bank for conciliation (Condon, et all., 2009). With respect to Baglihar, Pakistan's options are; (1) taking the issue of the gated spillways to the World Bank's court for mediation, (2) to make India agreed on the continue water flow for the project (Condon, et all., 2009)

\section{Tulbul Navigation/Wular Barrage}

Tulbul Navigation/ Wular Barage issue is still unsettled. A proposal forwarded by India on the construction of a barrier is to improve water flow along the Jhelum River, navigation of a 20-kilometer stretch between Sopur and Barmulla. However, Tulbul Navigation/Wular Barrage was started in 1984 and was finished in 1987 as Pakistan opposed it. Pakistan argument was

1. There would be a change brought by barrier in water flow on daily basis barrier.

2. It would be the violation of the Indus Water Treaty's provision of 1960 by preventing India from creating storage (except in limited amounts for the purpose of flood control)

3. This would harm Pakistan's three-canal i.e. Indus, Jhelum and Sutlej system downstream (Condon, et all.,)

\section{Kishanganga Dam}

The issue between India and Bangladesh over the proposed Kishanganga Dam is also pending and need to be resolved. According to the plan, India wants to build in the Jammu and Kashmir a 330 MW plant on the River Jhelum. On the Tulbul and Baglihar project, Pakistan faced the natural downstream effect of the project violation of the Indus Water Treaty.

Meanwhile, Pakistan is also planning to construct dam on the Jhelum River. Likely a project of India, this attempt would include creating a hydroelectric plant on Pakistan's side of Kashmir.

\section{The Baglihar, Indus water dispute: Role of Third and Fourth Parties}

Pakistan requested to the World Bank in January 2005 by asking to appoint a neutral expert for the Indus Treaty as Pakistan wants to build a dam on the Chenab River, which is one of the allocated river to Pakistan. On the other hand, India stated that the plant, being a run of- river, is allowed under the Treaty. Finally, Pakistan confronted this and maintained that it is not permitted under the Indus Treaty. The project would store and govern the flow of the Chenab River. Therefore, the water issue arises when the Indus Treaty allows India to do on allocated rivers to Pakistan, and fundamentally concerns water control and use (Salman, 2006).

\section{Bangladesh and India}

Bangladesh shares 54 trans boundary rivers with India, including the major rivers of the Ganges, Brahmaputra, and Meghna. For water management, a major issue between these two states has been erupted and still going on. If we have a look on map of Bangladesh, it offers a picture of the country's river systems. The mighty Ganges joins Bramaputra at the Jamma Channel which flows from the Himalayas, and bonds with the Meghna river near the Bay of Bengal and various other tributaries cross Bangladesh. Although, 93\% of the Ganges river flows from Bangladesh, making approximately 1,360 billion cubic meters of water into the Indian Ocean each year. During the monsoon seasons, it became vulnerable due to low elevation of Bangladesh flooding, on the other hand, Bangladesh is also disposed to scarcity during the "lean period" from May to January and; hence, management of mutual river resources is critical for Bangladesh (Salman, 2006)

\section{History of Water Disputes between Bangladesh and India}

In Bangladesh, the Ganges River is known as the Padma River. 
Bangladesh and India started negotiations in 1951 over the Ganges River. Bangladesh and India made a proposal regarding the construction of the Farraka Barrage in West Bengal. From 1960 to 1970s, there were ten meetings between these two countries held regarding the construction of barrage. Two states exchanged and collected substantial amount of data during this time period. In fact, in 1970, Pakistani and Indian representatives were agreed to create a committee on water delivery. Finally, it was decided between them that Farraka would continue to be the point of entrance for water distribution into East Pakistan.

\section{Current Disputes between Bangladesh and India}

There are various rivers crossing the Bangladesh's territory. Currently, there are some serious ongoing water disputes going on between the two countries, especially, India made efforts to divert water intended for Bangladesh. All these disputes include disagreements over the Farraka Barrage, Teesta river project, and the River Linking Project to connect the Ganges river to Brahmaputra the east to the Kaberi, and Mahanada rivers in the south. Through careful diplomacy, these water disputes have historically been resolved, it's a main concern as Bangladesh often considers that India treats it unjustly (Salman, 2000).

\section{The Farraka Barrage}

The most important concern for Bangladesh is Farraka Barrage. Through the Bhagirati-Hoogli, it diverts the water to river system in an effort to flush deposit from India's port city of Kolkata. Bangladesh claim that with construction of the Farraka Barrage, it would harm the economic well-being and agro-ecological of southern Bangladesh. A treaty was signed in 1996 between Bangladesh and India on sharing of the Ganges Waters. Though, due to some factors, the implementation of the Treaty ran into difficulties. Most importantly, to meet the needs of both states, there was not enough water in the river. This treaty remained in force for thirty years, expiring in 2026. Finally, these kind of solutions would address to meet the ever-increasing demands of both countries during the dry season and the basic issue of supplementing the flow of the Ganges (Salman, 2006).

A structure has been provided by bilateral treaties for resolving these points of conflict. The Ganges river treaty signed between India and Bangladesh on December 12, 1996, regulates the seasonal distribution of waters reaching Farraka, especially the accord on Ganges River waters and its delivery during the lean period.

\section{The Teesta River}

Another source of water dispute isthe Teesta River between Bangladesh and India. India constructed the Gazoldoba Barrage on its water in the late 1980s, which is 60 kilometers north of the Bangladesh border. The main purpose behind its construction was to divert water towards irrigation projects in northern West Bengal. Bangladesh built the Teesta Barrage 20 kilometers south of the Indian border in 1998. Bangladesh has revealed its reservations about the allocation of the Teesta's waters. In particular, Bangladesh opposes that India is increasingly diverting more water to Gazoldoba at the outflow of Bangladeshis downstream.

\section{The River Linking Project}

Water transfer the River Linking Project is a massive undertaking. Bangladesh competed with the offer, Bangladeshi official's take on it is that it would lead to flooding and would intensify the country's dry season. Additionally, Bangladesh claims that this project violates the International Law Association's 1966 Helsinki Rules on the uses of waters of International Rivers, which delivered an outline for the United Nations Convention on the Law of International Water courses of 1997 (Condon, et all., 2009).

\section{CONCLUSION}

Water is a blessing for the human beings and very beneficial as every person used it in day-to-day life accordingly. On one hand, water provides many benefits for the humans, but at the same time, it causes many disputes worldwide. These disputes over the water not only occurred on sea level but also on river 
water. These disputes can exist across the country, within the county or even among the provinces and federating units. Likewise, there are many disputes in South Asia over the water between India and Pakistan and between India and Bangladesh. There are many factors responsible, but one of most crucial one is that India is located on higher riparian and Bangladesh is located on the lower riparian. Similarly, India is located at higher riparian and Pakistan is in Lower riparian. Hence, India has an authority to stop the water and can divert it as three rivers flow from Indian held Kashmir to Pakistan. Additionally, India also divert the water through linking projects by constructing barrages on different rivers, which showed the unjustified behavior with its close neighbour Bangladesh. There were many accord/agreements signed between two states including Indus water Treaty and Teesta, which are famous one. These issues over the water are still existing and there are many dimensions which currently reawaken it.

\section{REFERENCES}

Ahmed, S. (2012). Water security: A threat to Pakistan and India. The Altanic Council, South Asian Center.

Noshab, F. \& Mushtaq, M. (2001). Water Disputes in South Asia. Institute of Strategic Studies Islamabad, 21(3), 78-104.

Condon, E., Hillmann, P., King, J., Lang, K. \& Patz, A. (2009). Resource Disputes in South Asia: Water Scarcity and the Potential for Interstate Conflict. La Follette School of Public Affairs.

Kureshy, K.U. (1997). A Geography of Pakistan. National Book Service.

Salman, M.A. (2000). International Water Disputes: A New Breed of Claims, Claimants, and Settlement Institutions. IWRA, Water International, 31(1).

Kugelman, M. \& Hathaway, R. (2009). Running On Empty: Pakistan's Water Crisis. Woodrow Wilson International Center for scholar Asian Program.

Sen, S.N. (1988). Ancient History of Bangladesh India and Pakistan. Vanguard press.

Robie I., \& Roy S. (1997). India-Bangladesh Water Dispute. ICE, Case study no.78.

Stanley, W. (1982). Roots of Confrontation in South Asia. Oxford University Press. 